\title{
Esterase Zymograms of Proteus and Providencia
}

\author{
By Ph. GOULLET \\ Laboratoire de Microbiologie, Faculté de Médécine \\ Xavier-Bichat, Université Paris VII \\ U.E.R. Biomédicale des Cordeliers, 75270 P C 06, France
}

(Received 20 August 1974; revised 28 September 1974)

\begin{abstract}
SUMMARY
The intracellular esterases of 80 strains of Proteus and Providencia were analysed by the acrylamide-agarose zymogram technique using several synthetic substrates.

The esterase bands were classified in five main groups. The $\alpha \mathrm{A}$-esterase bands hydrolysed $\alpha$-naphthyl acetate and were resistant or relatively insensitive to di-isofluoropropyl phosphate (DFP). The $\alpha \mathrm{B}$-esterase band hydrolysed both $\alpha$-naphthyl acetate and $\alpha$-naphthyl butyrate and were very sensitive to DFP. Both groups of esterase bands were inactivated by heat. The $\beta \mathrm{A}-$ and $\beta \mathrm{B}$-esterase bands hydrolysed $\beta$-naphthyl acetate and were sensitive to DFP; these were distinguishable by the difference in their relative activity towards $\beta$-naphthyl butyrate and in their relative stability to heat. The $\alpha \beta$-esterase bands hydrolysed $\alpha$ - and $\beta$-naphthyl acetates and $\alpha$ - and $\beta$-naphthyl butyrates; they were inactivated by heat and were sensitive to DFP.

The distribution of these esterase bands among the strains of Proteus and Providencia and their electrophoretic patterns established esterase profile types which correlate with the classification based on traditional bacteriological tests. The degree of inter-strain similarity in esterase pattern varied highly among species. The homogeneity of Proteus mirabilis and especially of Providencia stuartii contrasted with the heterogeneity of other species. This disparity suggests that the bacteria of the tribe Proteae have not the same degree of intra-specific differentiation in physico-chemical properties of esterases.
\end{abstract}

\section{INTRODUCTION}

Comparative studies of enzymes at the molecular level in enterobacteria were designed both to clarify the relationships between these organisms and to provide insight into the processes of molecular evolution and protein differentiation in bacteria (Bowman, Brubaker, Frischer \& Carson, 1967; Baptist, Shaw \& Mandel, I969; Murphy \& Mills, I969; Cocks \& Wilson, 1972).

The esterases (carboxylic ester hydrolases, EC. 3. I.I . ), which represent a broad spectrum of enzymes with common esterolytic activity but with distinct substrate specificity and electrophoretic properties, seemed suitable material for these investigations. Preliminary research revealed that representative species of Enterobacteriaceae had differences in the specificity and electrophoretic mobility of their esterases (Goullet, 1971). The Escherichia coli esterases were recently characterized by the zymogram procedure (Goullet, 1973). This report is concerned with the characterization and distribution of esterase bands in Proteus and Providencia. 
Table r. Strains used

\begin{tabular}{|c|c|c|c|c|c|c|c|}
\hline Organism & Strain $\%$ & $\begin{array}{c}\text { Date } \\
\text { of } \\
\text { Isolation }\end{array}$ & Code & Organism & Strain $\%$ & $\begin{array}{c}\text { Date } \\
\text { of } \\
\text { Isolation }\end{array}$ & Code \\
\hline \multirow[t]{11}{*}{ Proteus vulgaris } & LM3.70 & 1970 & I & \multirow[t]{3}{*}{ Biotype 2} & LM4.70 & 1970 & 44 \\
\hline & LM2.72 & 1972 & 2 & & LM2.7 I & I97I & 45 \\
\hline & LM3.72 & 1972 & 3 & & LM6.7I & I97I & 46 \\
\hline & LM4.72 & 1972 & 4 & \multirow[t]{2}{*}{ Biotype 3} & CR5.70 & 1970 & 47 \\
\hline & FM36 & I97I & 5 & & LMI. 73 & 1973 & 48 \\
\hline & HB70.99 & 1970 & 6 & \multirow{6}{*}{$\begin{array}{l}\text { Providencia } \\
\text { alcalifaciens } \dagger \\
\text { Biotype I }\end{array}$} & & & \\
\hline & HB7I. 29 & I97I & 7 & & & & \\
\hline & $\begin{array}{l}\text { HB7I. } 35 \\
\text { HB7I.63 }\end{array}$ & $\begin{array}{l}\text { I97I } \\
\text { I97I }\end{array}$ & $\begin{array}{l}8 \\
9\end{array}$ & & CR6.69 & 1969 & 49 \\
\hline & $\begin{array}{l}\text { HB7 1. } 03 \\
\text { HB7 I. } 64\end{array}$ & 1971 & 10 & & LM4.69 & 1969 & 50 \\
\hline & НВ72.67 & 1972 & I I & & LM5.70 & 1970 & $5 \mathrm{I}$ \\
\hline & НB 72.68 & 1972 & I 2 & & $\operatorname{LM} 7 \cdot 70$ & 1970 & 52 \\
\hline \multirow[t]{12}{*}{ P. mirabilis } & CR8.70 & 1970 & I3 & & LMI I.7I & I97I & 53 \\
\hline & LMI. 72 & 1972 & 14 & & LM6.72 & I 972 & 54 \\
\hline & LM4.72 & 1972 & I 5 & & LM8.72 & 1972 & 55 \\
\hline & LMI0.72 & 1972 & 16 & \multirow{7}{*}{ Biotype 2} & LM9.72 & 1972 & 56 \\
\hline & LMI 7.72 & 1972 & 17 & & LM7.69 & I969 & 57 \\
\hline & FM30 & 1970 & I 8 & & LM8.69 & I969 & 58 \\
\hline & Нв70.38 & I970 & 19 & & LM6.70 & 1970 & 59 \\
\hline & HB70.39 & 1970 & 20 & & LM7.72 & I 972 & 60 \\
\hline & HB70.42 & 1970 & 2 I & & LMI0.72 & I972 & $6 \mathrm{I}$ \\
\hline & HB70.43 & 1970 & 22 & & Per & I 968 & 62 \\
\hline & HB7 2.87 & 1972 & 23 & \multirow[t]{2}{*}{ Biotype 4} & LM2.73 & 1973 & 63 \\
\hline & HB72.89 & 1972 & 24 & & LM4.73 & 1973 & 64 \\
\hline \multirow[t]{12}{*}{ P. morganii } & LM3.70 & 1970 & 25 & \multirow{13}{*}{$\begin{array}{c}\text { Prov. stuartii } \dagger \\
\text { Biotype } 5\end{array}$} & & & \\
\hline & LMI 7.72 & 1972 & 26 & & LMI .7 I & I97I & 65 \\
\hline & CR6.72 & 1972 & 27 & & LM4.72 & 1972 & 66 \\
\hline & CRI 2.72 & 1972 & 28 & & LMI $4.72 \S$ & 1972 & 67 \\
\hline & CR54 I B 72 & 1972 & 29 & & LMI 5.72 & I 972 & 68 \\
\hline & IP55I 40 & - & 30 & & LMI $6.72 \S$ & 1972 & 69 \\
\hline & FM39 & I97I & $3 \mathrm{I}$ & & LMI 7.72 & 1972 & 70 \\
\hline & НB7 I. 28 & I97I & 32 & & FM38 & $197 I$ & $7 \mathrm{I}$ \\
\hline & HB7 I. 34 & $197 I$ & 33 & & HB7 I.3I & $197 \mathrm{I}$ & 72 \\
\hline & HB7 1.43 & 1971 & 34 & & HB71. $32 \S$ & I97I & 73 \\
\hline & HB7 I. 46 & I97I & 35 & & HB7 I. 53 & I97I & 74 \\
\hline & НВ7I. 84 & 197I & 36 & & HB7 I.54 & $197 \mathrm{I}$ & 75 \\
\hline \multirow{8}{*}{$\begin{array}{l}\text { P. rettgeri }{ }^{*} \\
\text { Biotype I }\end{array}$} & & & & & HB7 I.55 & I97I & 76 \\
\hline & CRI.7 I & I97I & 37 & \multirow{7}{*}{ Biotype 6} & LM $4.58 \S$ & 1958 & 77 \\
\hline & CR4.7I & I97I & 38 & & LMI. 65 & $\begin{array}{l}1902 \\
1965\end{array}$ & $\begin{array}{l}78 \\
79\end{array}$ \\
\hline & FM46 & I97I & 39 & & LM2.70§ & 1970 & 80 \\
\hline & HB7 1.36 & I97I & 40 & & & & \\
\hline & HB7 I. 37 & $197 \mathrm{I}$ & $4 I$ & & & & \\
\hline & HB7 I. 47 & 1971 & 42 & & & & \\
\hline & HB7 I.48 & I97I & 43 & & & & \\
\hline
\end{tabular}

* Biotypes according to Namioka \& Sakazaki (1958).

$\dagger$ Biotypes designation following characteristics defined by Ewing (1962) and Richard (1966).

* LM, Collection of L. Le Minor, Institut Pasteur, Paris, France; CR, collection of C. Richard, Institut Pasteur, Tangier, Morocco; FM, Laboratory of Microbiology, Faculty of Medicine, Paris, France; HB, Laboratory of Bacteriology, Beaujon Hospital, Paris-Clichy, France; IP, collection of l'Institut Pasteur, Paris; Per, Laboratory of Bacteriology, St Joseph Hospital, Paris, France. The CR, FM and HB strains were isolated from diverse materials (e.g. urine, faeces, blood, pus). The LM strains were isolated from diverse materials from various geographical locations.

$\S$ Strain 67 isolated from human urine in Clermont-Ferrand, France; strain 69 from meat in Bourg-enBresse, France; strain 73 from human urine in Clichy, France; strain 77 from human faeces in Brazzaville, Africa; strain 78 from human pus in Cayenne, South America; strain 80 from human pus in Antibes, France. 


\section{METHODS}

Bacteria and growth conditions. The 80 strains of Proteus and Providencia listed in Table I were inoculated in Fernbach flasks containing $500 \mathrm{ml} \mathrm{L}$ broth (Lennox, 1955) without glucose. Flasks were incubated at $37^{\circ} \mathrm{C}$ in a reciprocating water bath shaker (Monod \& Lapierre model, Etablissement Lecourt, Guyancourt, 78 France) at about 70 oscillations/min. Each strain was cultivated at least twice.

Preparation of extracts, heat denaturation, inhibition by di-iso-fluoropropyl-phosphate (DFP) and protein estimation were as described previously (Goullet, 1973).

Electrophoresis. Horizontal slab acrylamide-agarose gel electrophoresis was performed using $7 \%(\mathrm{w} / \mathrm{v})$ acrylamide and discontinuous tris-glycine buffer $\mathrm{pH} 8.7$ (Uriel, 1966). To compare relative mobilities the bacterial extracts were inserted side by side into the same gel and in some experiments the order of the extracts was changed. Bromophenol blue was the marker dye. The extracts were subjected to a constant voltage gradient of $7 \mathrm{~V} / \mathrm{cm}$ until the marker dye had travelled $13 \mathrm{~cm}$. The $M_{F}$ value was the ratio $(\%)$ of the distance moved by the esterase band to the distance moved by the dye front.

Esterase staining. The method of Uriel ( $196 \mathrm{I})$ was employed. The substrates $(0 \cdot 2 \mathrm{mg} / \mathrm{ml})$ used to detect and differentiate between the various zones of esterase activity were $\alpha$ naphthyl acetate, $\alpha$-naphthyl butyrate, $\beta$-naphthyl acetate and $\beta$-naphthyl butyrate (Sigma). Naphthanil diazo blue B (Dajac Laboratories, Philadelphia, Pennsylvania, U.S.A.) was the dye coupler.

\section{RESULTS}

\section{Esterase band differentiation by acetyl esters}

All the strains examined possessed at least one anodal band of strong esterase activity. Three main types of esterolytic activity were distinguished by the extent of hydrolysis of acetyl esters: (i) $\alpha$-esterase bands hydrolysing preferentially $\alpha$-naphthyl acetate; (ii) $\beta$ esterase bands hydrolysing preferentially $\beta$-naphthyl acetate; (iii) $\alpha \beta$-esterase bands degrading both $\alpha$-and $\beta$-naphthyl acetates (Fig. I).

\section{Proteus vulgaris}

Two characteristic esterase bands were defined (Fig. $2 a$ ). The $\alpha$-esterase band hydrolysed both $\alpha$-naphthyl acetate and $\alpha$-naphthyl butyrate. It reacted weakly with $\beta$-naphthyl acetate. This esterase was inhibited by DFP $\left(\mathrm{IO}^{-5} \mathrm{M}\right)$ and inactivated after 10 min at $60{ }^{\circ} \mathrm{C}$. The $\beta$-esterase band hydrolysed both $\beta$-naphthyl acetate and $\beta$-naphthyl butyrate. It reacted very weakly with $\alpha$-naphthyl acetate. This esterase was inhibited by $10^{-4} \mathrm{M}$-DFP and showed residual activity after $10 \mathrm{~min}$ at $60^{\circ} \mathrm{C}$. The $\alpha$ - and $\beta$-esterase bands were clearly visible in the I2 strains (Fig. $2 b$ ) except strain 4 where the $\alpha$-esterase band was only faint. The $\alpha$ - and $\beta$-esterase bands showed several types of electrophoretic mobility. Except for strain I, all $\alpha$-esterase bands migrated faster than $\beta$-esterase bands. In Fig. $2 b$ the strains are arranged in order of increasing mobility of the $\beta$-esterase bands. $\alpha$-Esterase bands range from $M_{l} \approx 58$ to $M_{F} \approx 73$ and $\beta$-esterase bands from $M_{F} \approx 52$ to $M_{F} \approx 67$.

\section{Proteus mirabilis}

The strains of $P$. mirabilis were characterized by one set of $\alpha$-esterase bands and a single $\beta$-esterase band (Fig. $3 a$ ). The three $\alpha$-esterase bands hydrolysed almost only $\alpha$-naphthyl acetate; the slowest-moving band was the most active. All bands disappeared after 10 min at $60{ }^{\circ} \mathrm{C}$ but remained active in the presence of $10^{-3} \mathrm{M}$-DFP. The $\alpha$-bands from different 


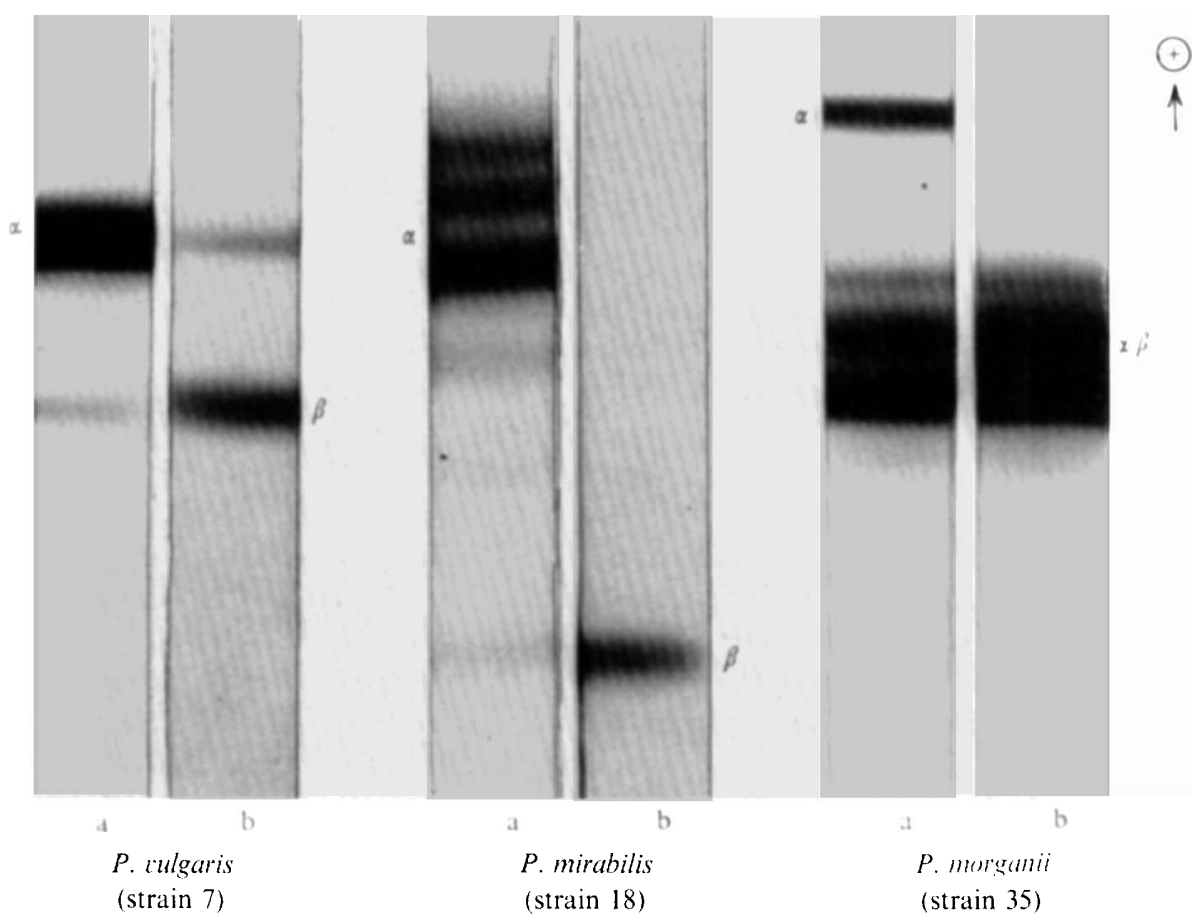

Fig. I. Esterase band differentiation by acetyl esters. Substrates used: a, $\alpha$-naphthyl acetate; $\mathrm{b}, \beta$-naphthyl acetate. $\alpha, \alpha$-Esterase band; $\beta, \beta$-esterase band; $\alpha \beta, \alpha \beta$-esterase band.

strains showed either fast or slow migration (Fig. $3 b$ ). Compared with the slow pattern, the three components of the fast pattern are displaced in a parallel fashion towards the anode. The $\beta$-esterase band has characteristics similar to those of $P$. vulgaris. All $\beta$-esterase bands of $P$. mirabilis strains exhibited electrophoretic uniformity $\left(M_{F} \approx 48\right)$.

\section{Proteus morganii}

This was characterized by very strong esterase activity, principally located in a set of $\alpha \beta$-esterase bands which hydrolysed $\alpha$-naphthyl acetate, $\alpha$-naphthyl butyrate, $\beta$-naphthyl acetate and $\beta$-naphthyl butyrate (Fig. $4 a$ ). The slowest-moving band was the most densely coloured with each substrate. All bands were inactivated after $10 \mathrm{~min}$ at $60{ }^{\circ} \mathrm{C}$ and inhibited by $10^{-3} \mathrm{M}$-DFP. One $\alpha$-esterase band $\left(M_{F} \approx 92\right)$ with two narrow anodic components exhibited activity only with $\alpha$-naphthyl acetate. This band was inactivated by heat and partially inhibited by $\mathrm{IO}^{-3} \mathrm{M}$-DFP. Finally, one diffuse and slower-migrating band $\left(M_{F} \approx \mathrm{I} 6\right)$ reacted weakly with $\beta$-naphthyl acetate. Electrophoretic variations of $\alpha \beta$-esterase bands were observed (Fig. $4 b$ ).

\section{Proteus rettgeri}

In typical cases, $P$. rettger $i$ shows two major bands, the $\alpha$-esterase band and the $\beta$-esterase band, and one set of minor bands (Fig. 5a). The major $\alpha$-esterase band hydrolysed both $\alpha$-naphthyl acetate and $\alpha$-naphthyl butyrate and reacted weakly with $\beta$-naphthyl acetate. This esterase was inhibited by $10^{-5} \mathrm{M}-\mathrm{DFP}$ and inactivated after $\mathrm{Io} \min$ at $60{ }^{\circ} \mathrm{C}$. The $\beta$-esterase band migrated more slowly than $\alpha$-esterase and hydrolysed $\beta$-naphthyl acetate. It was weakly active towards $\beta$-naphthyl butyrate and relatively stable at $60{ }^{\circ} \mathrm{C}$. The 


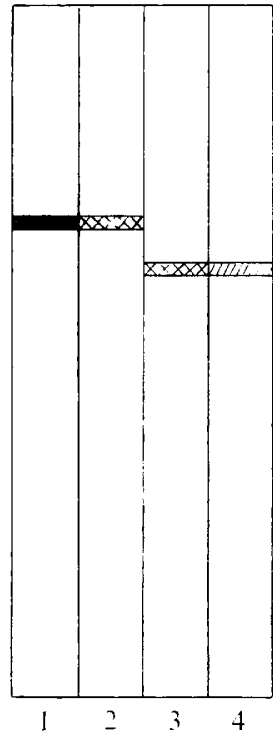

(a)

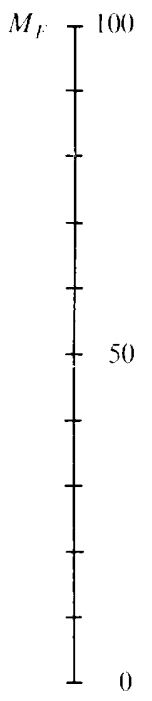

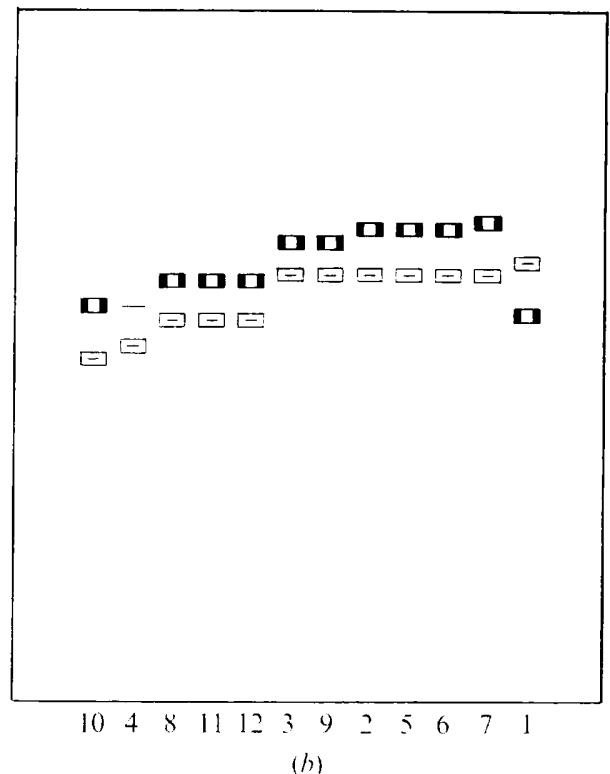

Fig. 2. Proteus vulgaris. (a) Schematic representation of mobility and activity of esterase bands (strain 6). Substrates used: I, $\alpha$-naphthyl acetate; $2, \alpha$-naphthyl butyrate; $3, \beta$-naphthyl acetate; 4, $\beta$-naphthyl butyrate. 0 , Origin. For each band only preferential hydrolysing activities are represented. The shading in Figs. 2, 3, 4, 5, 7 and 8 indicates the relative intensity of staining: $>>$ DZA $>$ DZ. (b) Diagram of esterase patterns of the $\mathrm{I} 2$ strains arranged in order of increasing mobility of $\beta$-esterase bands. $\square, \alpha$-esterase band hydrolysing both $\alpha$ naphthyl acetate and $\alpha$-naphthyl butyrate; $\square, \beta$-esterase band.

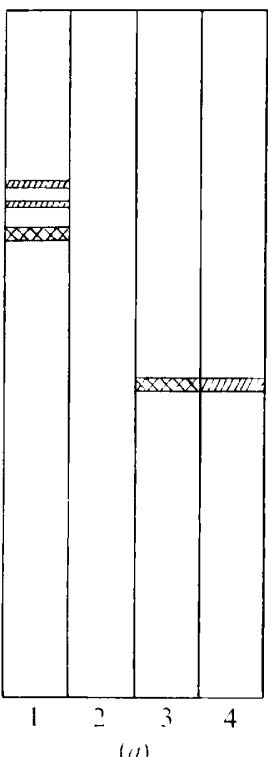

(a)

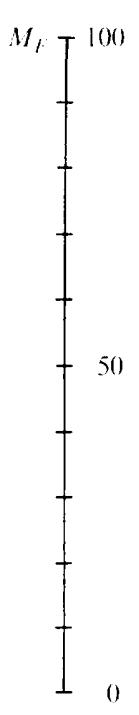

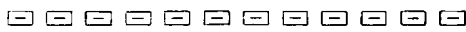

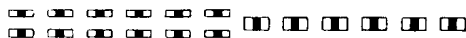

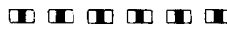

舟

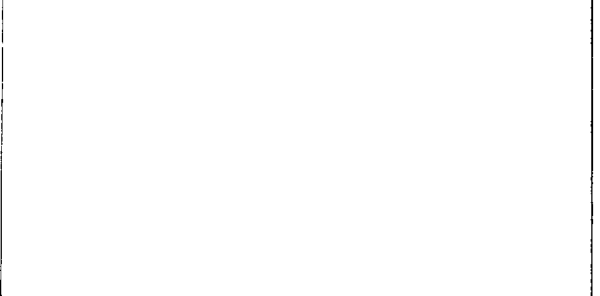

$13 \quad 1516192023141718212224$

(b)

Fig. 3. Proteus mirabilis. (a) Schematic representation of mobility and activity of esterase bands (strain 15). For key, see Fig. 2. (b) Diagram of esterase patterns of the 12 strains arranged in order of increasing mobility of $\alpha$-esterase bands. $\square \square, \alpha$-esterase band hydrolysing $\alpha$-naphthyl acetate; $\rightleftharpoons$, $\beta$-esterase band. 


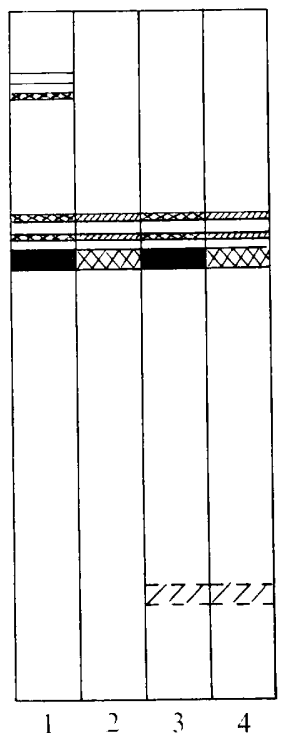

(a)

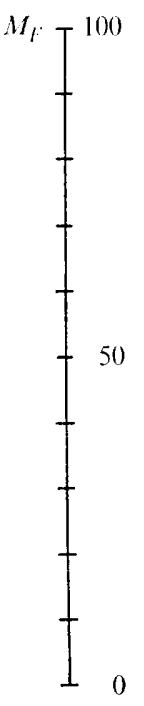

$28 \quad 29 \quad 31 \quad 32 \quad 33 \quad 34 \quad 352627 \quad 30 \quad 3625$

(b)

Fig. 4. Proteus morganii. (a) Schematic representation of mobility and activity of esterase bands (strain 32). For key, see Fig. 2. (b) Diagram of esterase patterns of the 12 strains arranged in order of increasing mobility of $\alpha \beta$-esterase bands. $\square \square, \alpha$-esterase band hydrolysing $\alpha$-naphthyl acetate; $\square, \alpha \beta$-esterase band.

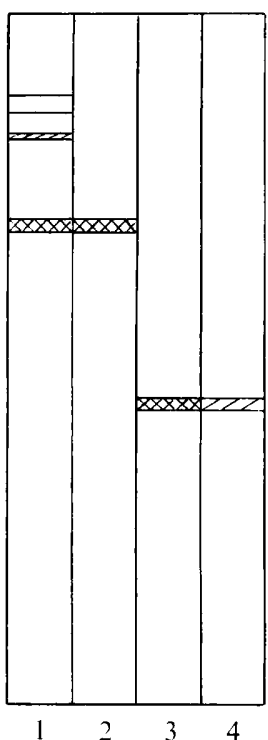

(a)

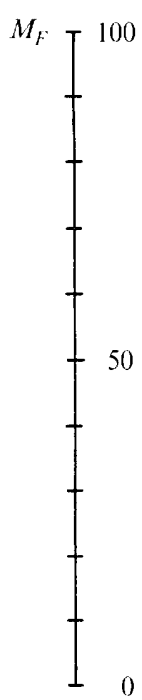

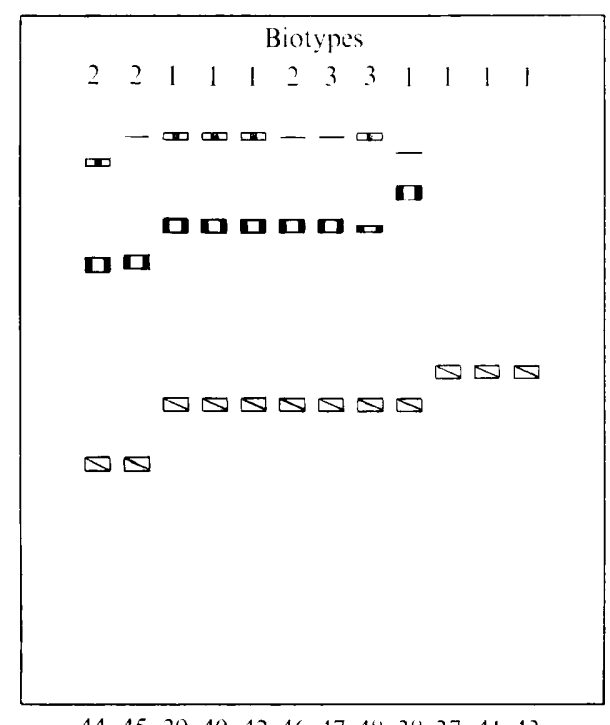

$\begin{array}{lllllllllllll}44 & 45 & 40 & 42 & 46 & 47 & 48 & 38 & 37 & 41 & 43\end{array}$

(b)

Fig. 5. Proteus rettgeri. (a) Schematic representation of mobility and activity of esterase bands (strain 40). For key, see Fig. 2. (b) Diagram of esterase pattern of the 12 strains arranged in order of increasing mobility of $\beta$-esterase bands. $\square \square, \alpha$-esterase band hydrolysing $\alpha$-naphthyl acetate; $\square, \alpha$-esterase band hydrolysing both $\alpha$-naphthyl acetate and $\alpha$-naphthyl butyrate; $\square$ $\beta$-esterase band. 
a

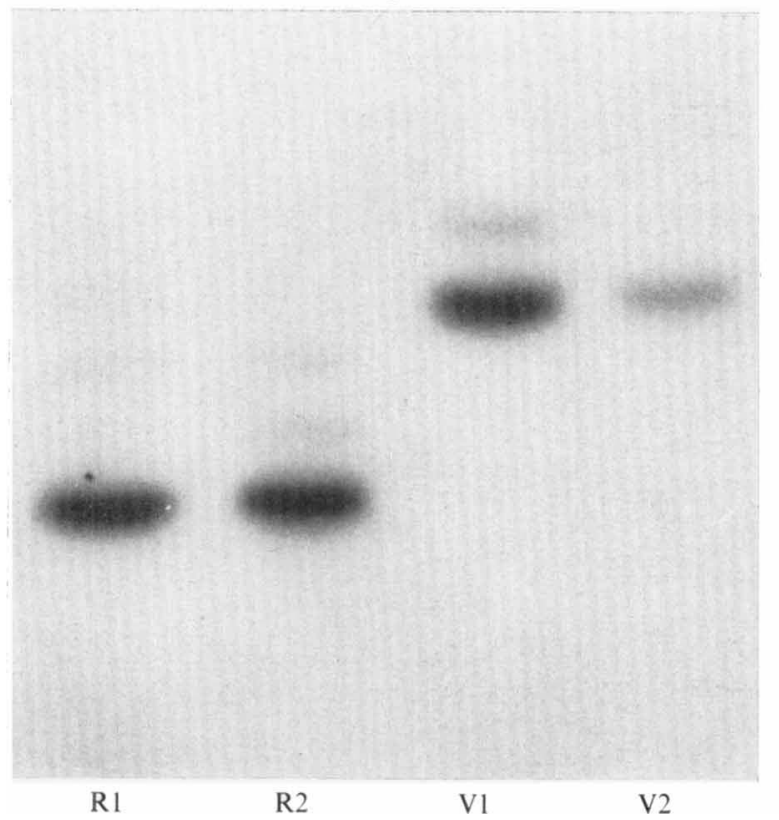

b

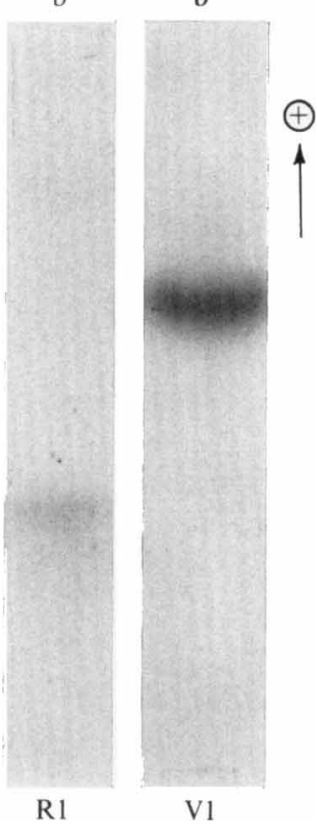

Fig. 6. Difference between $\beta$-esterase bands of $P$. rettgeri and of $P$. vulgaris. Substrates used: a, $\beta$-naphthyl acetate; $\mathrm{b}, \beta$-naphthyl butyrate. $\mathrm{R}, P$. rettgeri; V, $P$. vulgaris. I, Untreated preparation; 2 , heated at $60 \mathrm{C}$ for $10 \mathrm{~min}$.

$\alpha$-esterase minor bands consisted of a set of components hydrolysing $\alpha$-naphthyl acetate and inactivated by heat. Each variety of esterase bands showed several types of mobility (Fig. $5 b$ ). The major $\alpha$-esterase band was not detected in strains $37,4 \mathrm{I}$ and 43 . No biotype pattern was noted. Figure 6 illustrates the different behaviour of the $\beta$-esterase bands of $P$. vulgaris and $P$. rettgeri.

\section{Providencia alcalifaciens}

In typical cases four distinct bands may be recognized (Fig. 7a). The $\alpha \beta$-esterase band was broad and intensely coloured. Its hydrolytic activity was similar to that of $P$. morganii; it was inactivated after $10 \mathrm{~min}$ at $60^{\circ} \mathrm{C}$ and inhibited by $10^{-3} \mathrm{M}-\mathrm{DFP}$. The fast-moving $\alpha$-esterase band $\left(M_{F} \approx 92\right)$ was weak and presented characteristics similar to the corresponding band of $P$. morganii. The other $\alpha$-esterase band $\left(M_{F} \approx 65\right)$ was more visible and hydrolysed both $\alpha$-naphthyl acetate and $\alpha$-naphthyl butyrate. It was inactivated by heat and was inhibited by $10^{-5} \mathrm{M}$-DFP. The $\beta$-esterase band was apparently similar to that of $P$. rettgeri; it was detected in all strains except strain 63 and showed two main types of mobility (Fig. $7 b$ ). Considerable variations were observed both in the number and in the electrophoretic mobility of other esterase bands: the fast-moving $\alpha$-band is often undetected and the slower $\alpha$-band showed several types of mobility; the $\alpha \beta$-esterase band was detected in only six strains and two bands were observed in strains 56 and $6 \mathrm{I}$.

\section{Providencia stuartii}

Two major bands of $\alpha$ - and $\beta$-esterases and one or two minor bands were found (Fig. $8 a$ ). The $\alpha$-esterase band $\left(M_{F} \approx 75\right)$ hydrolysed $\alpha$-naphthyl acetate. It disappeared after ro min 


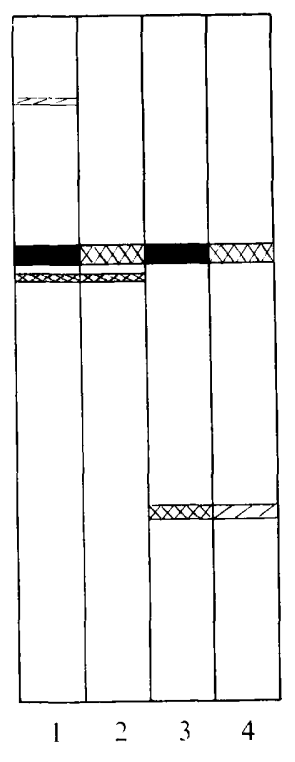

(a)

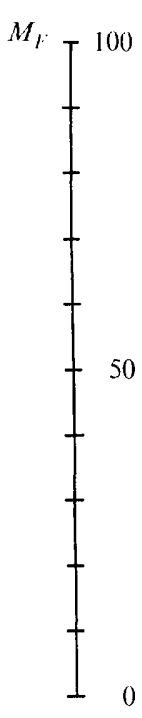

55605451566153574952625058596463

(b)

Fig. 7. Providencia alcalifaciens. (a) Schematic representation of mobility and activity of esterase bands (strain 55). For key, see Fig. 2. (b) Diagram of esterase patterns of the 16 strains arranged in order of increasing mobility of the $\beta$-esterase bands. $\square \square, \alpha$-esterase band hydrolysing $\alpha$ naphthyl acetate; $\square, \alpha$-esterase band hydrolysing both $\alpha$-naphthyl acetate and $\alpha$-naphthyl butyrate; $\square, \beta$-esterase band; $\square, \alpha \beta$-esterase band.

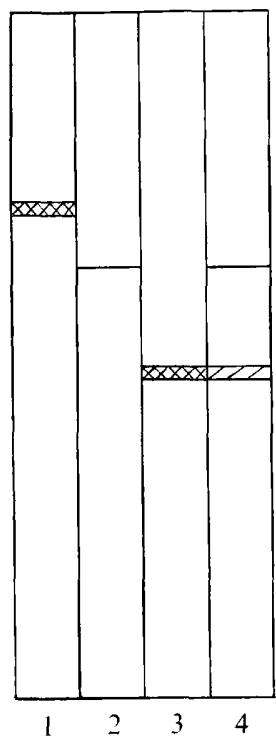

(a)

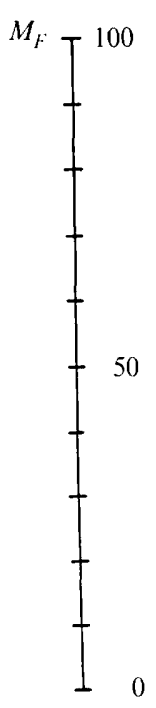

$6566 \quad 6768697071727374757677787980$

(b)

Fig. 8. Providencia stuartii. (a) Schematic representation of mobility and activity of esterase bands (strain 72). The cathodal band is not represented. For key, see Fig. 2. (b) Diagram of esterase patterns of the 16 strains. $\square \square$, $\alpha$-esterase band; $\square$, $\beta$-esterase band 
Table 2. Preliminary classification of esterase bands of Proteus and Providencia

\begin{tabular}{|c|c|c|c|c|c|c|}
\hline $\begin{array}{c}\text { Group } \\
\text { of } \\
\text { esterases }\end{array}$ & $\begin{array}{l}\text { Acetyl ester } \\
\text { preferentially } \\
\text { hydrolysed* }\end{array}$ & $\begin{array}{l}\text { Butyryl } \\
\text { ester } \\
\text { hydro- } \\
\text { lysed } \dagger\end{array}$ & $\begin{array}{l}\text { In- } \\
\text { activation } \\
\text { after } \\
10 \mathrm{~min} \\
\text { at } 60^{\circ} \mathrm{C}\end{array}$ & $\begin{array}{l}\text { Inhibitory } \\
\text { concn of } \\
\text { DFP (M) }\end{array}$ & $\begin{array}{c}\text { Electrophoretic } \\
\text { band } \\
\text { characteristics }\end{array}$ & Organisms \\
\hline \multirow[t]{3}{*}{$\begin{array}{c}\alpha \text { A-Esterase bands } \\
(\square \square)\end{array}$} & $\alpha \mathrm{NA}$ & $( \pm)$ & - & $10^{-3}$ & Fast-movingt & $\begin{array}{l}\text { P. morganii } \\
\text { Prov. alcalifaciens }\end{array}$ \\
\hline & & & - & (Resistant & Several & P. mirabilis \\
\hline & & & & to $10^{-3} \mathrm{M}$ ) & Single & Prov. stuartii \\
\hline$\alpha \mathrm{B}$-Esterase bands & $\alpha \mathrm{NA}$ & ++ & - & $10^{-5}$ & Single & $\begin{array}{l}\text { P. vulgaris } \\
\text { P. rettgeri } \\
\text { Prov. alcalifaciens }\end{array}$ \\
\hline$\beta \mathrm{A}$-Esterase bands & $\beta$ NA & + & ++ & $10^{-4}$ & $\begin{array}{l}\text { Single (migrating } \\
\text { slower than } \alpha- \\
\text { esterase band) }\end{array}$ & $\begin{array}{l}\text { P. rettgeri } \\
\text { Prov. alcalifaciens } \\
\text { Prov. stuartii }\end{array}$ \\
\hline$\beta \mathrm{B}$-Esterase bands & $\beta \mathrm{NA}$ & $+t$ & + & $10^{-4}$ & $\begin{array}{l}\text { Single (migrating } \\
\text { slower than } \alpha- \\
\text { esterase-band) }\end{array}$ & $\begin{array}{l}\text { P. vulgaris } \\
\text { P. mirabilis }\end{array}$ \\
\hline$\alpha \beta$-Esterase bands & $\begin{array}{l}\text { Both } \alpha \text { NA } \\
\text { and } \beta \text { NA }\end{array}$ & ++ & - & $10^{-3}$ & $\begin{array}{l}\text { Several } \\
\text { Single or double }\end{array}$ & $\begin{array}{l}\text { P. morganii } \\
\text { Prov. alcalifaciens }\end{array}$ \\
\hline
\end{tabular}

* $\alpha$ NA, $\alpha$-naphthyl acetate; $\beta$ NA, $\beta$-naphthyl acetate.

$\dagger \alpha$-Naphthyl butyrate for $\alpha$-esterase bands, $\beta$-naphthyl butyrate for $\beta$-esterase bands, $\alpha$-and $\beta$-naphthyl butyrates for $\alpha \beta$-esterase bands. ++ , Strong esterase activity; + , weak activity; \pm , very weak activity; - , no activity.

$\ddagger M_{F}>90$.

at $60{ }^{\circ} \mathrm{C}$ but remained active in the presence of $10^{-3} \mathrm{M}$-DFP. The $\beta$-esterase band $\left(M_{F} \approx 50\right)$ presented characteristics corresponding to those of $P$. rettgeri and Prov. alcalifaciens. One very fine minor band reacting with $\alpha$ - and $\beta$-naphthyl butyrates was observed. Finally, one diffuse cathodal band reacted with $\alpha$ - and $\beta$-naphthyl acetates.

A striking feature was that all the $\alpha$ - and the $\beta$-esterase bands presented electrophoretic uniformity with respect to one another (Fig. $8 b$ ). To confirm these results, the extracts of strains $67,69,73,77,78$ and 80 (for details of their origins see Table 1) were analysed by acrylamide-agarose electrophoresis in a citrate phosphate buffer system $\mathrm{pH} 7$ (Cocks $\&$ Wilson, 1972). Under these conditions the $\alpha$ - and $\beta$-esterase bands also presented electrophoretic uniformity ( $\alpha$-bands, $M_{F} \approx 46 ; \beta$-bands, $M_{F} \approx 27$ ). Thus despite distinct biotypes and origins, the Prov. stuartii strains appeared practically identical in terms of the $\alpha$ - and $\beta$-esterase band mobilities.

\section{DISCUSSION}

The results obtained by acrylamide-agarose gel electrophoresis and subsequent enzyme staining of extracts from 80 strains of Proteus and Providencia demonstrated different types of esterase bands.

On the basis of their differential hydrolytic activity, their sensitivity to heat or to DFP and their electrophoretic pattern, a preliminary classification may be proposed (Table 2). The $\alpha$-esterase bands which hydrolyse $\alpha$-naphthyl acetate preferentially and are inactivated by heat may be clearly separated into two principal groups: (i) the $\alpha \mathrm{A}$-esterase bands which have a very weak activity or no detectable activity towards $\alpha$-naphthyl butyrate and 
which are resistant or relatively insensitive to DFP; (ii) the $\alpha$ B-esterase bands which possess strong activity towards $\alpha$-naphthyl butyrate and are highly sensitive to DFP.

The $\beta$-esterase bands preferentially hydrolysing $\beta$-naphthyl acetate and inhibited by $\mathrm{IO}^{-4} \mathrm{M}$-DFP may also be divided into two groups: (i) the $\beta$ A-esterase bands which react weakly with $\beta$-naphthyl butyrate and remain relatively stable after 10 min at $60{ }^{\circ} \mathrm{C}$; (ii) the $\beta$ B-esterase bands which are more active towards $\beta$-naphthyl butyrate but less heatstable.

The $\alpha \beta$-esterase bands of $P$. morganii and Prov. alcalifaciens show a high and broad hydrolysing activity. Under the experimental conditions employed these two esterase bands are indistinguishable by their specificity and by their heat and DFP sensitivity but they differ by electrophoretic pattern.

Major esterase band profiles permitted species identification of $P$. vulgaris, $P$. mirabilis, $P$. morganii and Prov. stuartii. It is more difficult to differentiate between $P$. rettgeri and Prov. alcalifaciens when the $\alpha \beta$-esterase band of this latter organism is not detected. Separation could be made eventually by comparing esterase band mobilities and by examining some fainter bands.

The intra-species similarities of esterase patterns vary considerably. The homogeneity of $P$. mirabilis and especially of Prov. stuartii contrasts with the heterogeneity of other species. This disparity suggests that the bacteria of the tribe Proteae have not the same degree of intra-specific differentiation in physico-chemical properties of esterases.

The author thanks Madame Colette Gaillard for technical assistance.

\section{REFERENCES}

Baptist, J. N., Shaw, C. R. \& MANDEL, M. (I969). Zone electrophoresis of enzymes in bacterial taxonomy. Journal of Bacteriology 99, I80-I88.

Bowman, J. E., Brubaker, R. R., Frischer, H. \& Carson, P. E. (1967). Characterization of Enterobacteria by starch-gel electrophoresis of glucose-6-phosphate dehydrogenase and phosphogluconate dehydrogenase. Journal of Bacteriology 94, 544-55I.

Cocks, G. T. \& WiLson, A. C. (1972). Enzyme evolution in the Enterobacteriaceae. Journal of Bacteriology Iro, $793-802$.

EwING, W. H. (1962). The tribe Proteae: its nomenclature and taxonomy. International Bulletin of Bacteriological Nomenclature and Taxonomy 12, 93-102.

Goullet, PH. (1971). Caractérisation et répartition moléculaire des activités estérasiques de diverses Enterobacteriaceae. Comptes rendus hebdomadaire des séances de l'Académie des sciences D273, 1884I 887 .

Goullet, PH. (1973). An esterase zymogram of Escherichia coli. Journal of General Microbiology 77, 27-35.

Lennox, E. S. (1955). Transduction of linked genetic characters of the host by bacteriophage Pr. Virology I, $190-206$.

Murphy, T. M. \& Mills, S. E. (1969). Immunochemical and enzymatic comparisons of the tryptophan synthase $\alpha$ subunits from five species of Énterobacteriaceae. Journal of Bacteriology 97, I $310-1320$.

Namioka, S. H. \& Sakazaki, R. (1958). Étude sur les Rettgerella. Annales de l'Institut Pasteur 94, 485499.

RICHARD, C. (1966). Caractères biochimiques des biotypes de Providencia; leurs rapports avec le genre Rettgerella. Annales de l'Institut Pasteur 110, 105-I14.

URIEL, J. (I96I). Caractérisation des cholinestérases et d'autres estérases carboxyliques après électrophorèse et immunoélectrophorèse en gélose (application à l'étude des estérases du sérum humain normal). Annales de l'Institut Pasteur ror, 104-1 19.

Uriel, J. (I966). Méthode d'électrophorèse dans des gels d'acrylamide-agarose. Bulletin de la Société de chimie biologique 48, 969-982. 